\title{
Hormonal Effect on Mandarin Orange (Citrus reticulata Blanco) Micro-propagation
}

\author{
Resham Babu Amgai ${ }^{*}$, Hari Kumar Prasai ${ }^{1}$, Yama Raj Pandey ${ }^{1}$ \\ ${ }^{1}$ Regional Agriculture Research Station-Lumle, Nepal Agricultural Research Council, Kaski, Nepal.
}

\begin{abstract}
Tissue culture is the best option to produce disease free seedling of the fruit crop rapidly. Micro-propagation and use of the in-vitro grafting (micro-grafting) is very helpful for production of virus free planting materials in mandarin. Different levels of the in-vitro hormone affect the success of callusing, shooting and plant regeneration in mandarin. Shoot bud, flower bud and in-vitro seedling epicotyl was used as explants to study the hormonal effect on mandarin micro-propagation. Similarly, 10 levels of BAP and IAA combination on MS media for mandarin tissue culture were used. Observation was done for 100 test tubes per treatment combination after 4, 8 and 12 weeks of culture. Data was arc sine transformed for analysis. Shooting from explants was significantly higher $(71.72 \%)$ on medium level of the BAP $(0.5 \mathrm{mg} / \mathrm{L})$ and IAA $(0.2 \mathrm{mg} / \mathrm{L}) \mathrm{using}$ in-vitro seedling stem as explant, however, it was $27.91 \%$ for stem bud as explant. Stem bud showed higher level of callusing $(6.15 \%, \mathrm{p}<0.001)$ in mandarin orange. However, flower bud didn't develop shoot in mandarin tissue culture. Increment of the in-vitro regeneration of the shooting and callusing was observed by the increment of the in-vitro incubation duration in mandarin orange tissue culture.
\end{abstract}

Keywords: mandarin orange, Citrus reticulata, in-vitro shooting, hormone, callusing.

*Corresponding Author

Email: reshamamgain@yahoo.com

\section{Introduction}

Citrus is the major fruit in Nepal that shares $26.84 \%$ of the total fruit growing area in the country. Mandarin orange (Citrus reticulata Balnco) is predominant occupying 26495 ha i.e. $71.65 \%$ of total citrus growing area in Nepal [1]. Nepalese Mandarin industry is facing a lot of citrus decline related problem that can be overcomed through use of disease free planting materials. Seed propagation is $85-90 \%$ in Mandarin; however, grafting is gaining popularity [2].

Certain pathogens are difficult to be eliminated from mother plant like citrus exocortis and stubborn, which might be eliminated by a process of shoot tip grafting in-vitro. Indian Citrus Ringspot Virus (ICRSV) can also be eliminated by using the shoot tip $(0.7 \mathrm{~mm})$ of sprouts of cultured nodal segment of Kinnow through in-vitro shoot tip grafting (micro-grafting) [3].

Similarly, plant obtained by micro-grafting do not have the same problems as nucellar plants such as reversion to juvenile state, excessive thorniness, vigorous and upright habit of growth, slowness to fruiting, alternate bearing in early years and physical differences in fruit characteristics [4]. The scion taken from in-vitro cultured buds produced healthy plants than scions from whole trees [5]. Similarly, it reduced the dependency for the seasonal flush of the mandarin for scion during micro-grafting.

Youtsey [6] reported that rate of successful grafts (as high as $50 \%$ ) often influenced by the condition of the plant material and time of year. Therefore, the continue supply of the in-vitro scion material will enhance the micro-grafting efficiency of citrus for all year around.

Similarly, in-vitro callusing, regeneration and conservation of mandarin is very important. Martin et al. [7] also established a protocol by using nodal stem segments of sweet orange for in-vitro conservation for two years and its recovery that was successfully applied on mandarin. Therefore, this study was conducted to identify the suitable in-vitro culture media for mandarin in-vitro shooting and callusing.

\section{Materials and Methods Variety and Ex-plant Selection}

Mandarin orange variety 'Manakamana Local' was used in this study. Immature shoot with single bud, mature flower bud and in-vitro seedling epicotyl (2 $\mathrm{cm}$ long) was used as ex-plant. In-vitro seedling of 8 week was used to harvest epicotyl. Explants were collected during citrus flowering season. Immature shoot with single bud was used as explant to study the shooting from callus. 
Table 1: Different level of growth hormone used in the in-vitro culture of mandarin [T denotes media composition with $\mathrm{pH}$ 5.70]

\begin{tabular}{|c|c|c|c|c|c|c|c|c|c|c|}
\hline \multirow{2}{*}{ Hormone } & \multicolumn{10}{|c|}{ Concentration $(\mathrm{mg} / \mathrm{l})$} \\
\hline & $\mathrm{T} 1$ & $\mathrm{~T} 2$ & T3 & $\mathrm{T} 4$ & T5 & T6 & $\mathrm{T} 7$ & T8 & T9 & $\mathrm{T} 10$ \\
\hline $\begin{array}{l}\text { 6-Benzylaminopurine } \\
\text { (BAP) }\end{array}$ & 0 & 0 & 0.5 & 0.5 & 1.0 & 1.0 & 2.0 & 2.0 & 4.0 & 4.0 \\
\hline $\begin{array}{l}\text { Indole-3-acetic acid } \\
\text { (IAA) }\end{array}$ & 0 & 0.2 & 0 & 0.2 & 0 & 0.2 & 0 & 0.2 & 0 & 0.2 \\
\hline
\end{tabular}

\section{In-vitro culture media}

Different hormonal composition was applied for the Murasige and Skoog (MS) basal media [8] (as in Table 1)

\section{Ex-plant culture and incubation}

The explant was sterilized with $4 \%$ sodium hypochlorite solution for 3 minutes. It was washed with distilled water for 3 times and cultured on test tube with $20 \mathrm{ml}$ specified media (Table 1). The test tubes were incubated at $22 \pm 2{ }^{\circ} \mathrm{C}$ with $16: 8$ hours light: dark.

4. Observation and data analysis

Observation was taken after 4 weeks, 8 weeks and 12 weeks after incubation. Three replications were used for each treatment. Observation for each treatment consists of 100 test tubes. Each test tube is observed for callusing and shooting directly from ex-plant or from callus. Data was angular transformed for variance analysis.

\section{Results and discussion} Shooting

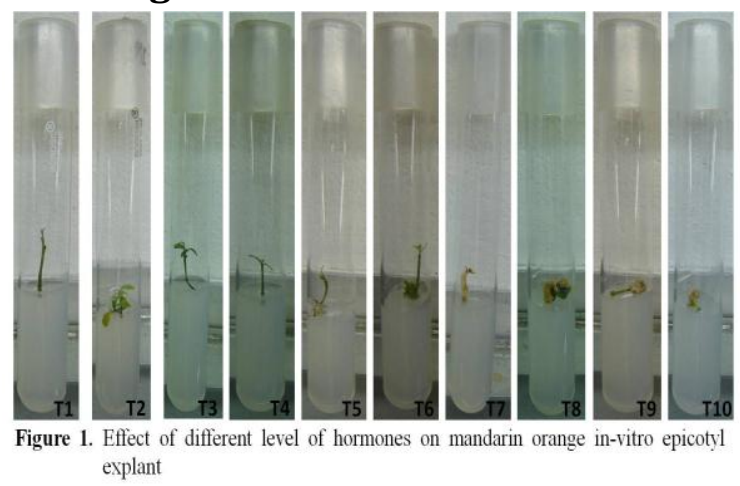

Flower bud don't show shooting directly, however, it showed highest callusing rate $(81.77 \%)$. Similarly, highest shooting directly from explants (Figure 1) $(31.195 \%)$ was observed from in-vitro epicotyle (Table 2). Mendes et al. [9] also observed that epicotyl explants from 35-day-old seedlings produced significantly more shoots per explants in sweet orange variety 'Para'.

No shooting from callus was observed on MS basal media+BAP $4 \mathrm{mg} / 1$ with/without IAA. Similarly, highest shooting from callus (24\%) was observed on directly from explant.

Shooting directly from explant and from callus was found increased by increment of the incubation period (Figure 2). Similarly, significant interaction between explant and media, explant and incubation

Table 2: Mean Percentage of the callusing and shooting directly from explants observed according to different plant parts used as explants. [Value in parentheses is angular transformation; letters after mean is the comparisons using Duncan's Multiple Range Test (DMRT) for mean differences]

\begin{tabular}{lcc} 
Explant & $\begin{array}{c}\text { Callusing from } \\
\text { explant }\end{array}$ & $\begin{array}{c}\text { Shooting directly } \\
\text { from explant }\end{array}$ \\
\hline $\begin{array}{l}\text { Immature shoot with } \\
\text { single bud }\end{array}$ & $21.043(21.175) \mathrm{b}$ & $19.69(19.002) \mathrm{b}$ \\
Flower bud & $81.77(71.872) \mathrm{a}$ & No Shooting \\
$\begin{array}{l}\text { In-vitro shoot tip } \\
(2 \mathrm{~cm} \text { long })\end{array}$ & $21.216(20.347) \mathrm{b}$ & $31.195(33.431) \mathrm{a}$ \\
$\quad \begin{array}{l}\text { Probability } \\
\text { LSD at } 5 \%\end{array}$ & $<.001$ & $<0.001$ \\
$\quad$ CV\% & 3.829 & 4.494 \\
\end{tabular}

period was observed for callusing from explant and shooting directly from explant. No interaction was observed among explant, media and incubation

\section{Callusing}

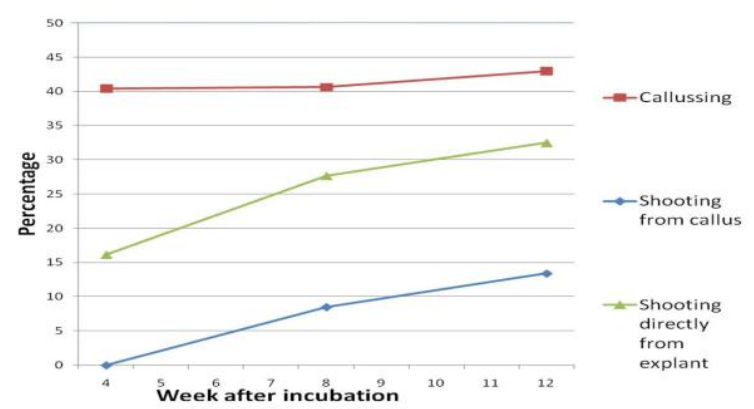

Figure 2. Mean percentage of the callusing, shooting from callus and shooting dir from explant over incubation period in mandarin

Flower bud gave highest callusing for all media composition (Figure 3). It was highest on MS basal media $+0.5 \mathrm{mg} / 1 \mathrm{BAP}$ with or without $0.2 \mathrm{mg} / 1 \mathrm{IAA}$ and MS basal media $+2 \mathrm{mg} / 1 \mathrm{BAP}$ from flower bud explant. No callusing was observed under hormonal level $1 \mathrm{mg} / 1 \mathrm{BAP}$ in in-vitro shoot tip. Highest callusing from immature shoot with single bud was observed on MS basal media $+1 \mathrm{mg} / 1 \mathrm{BAP}+0.2 \mathrm{mg} / 1$ IAA (Table 5). 
Table 3: Mean Percentage of the callusing, shooting directly from explants and shooting from callus observed according to different media composition. [Value in parentheses is angular transformation; letters after mean is the comparisons using Duncan's Multiple Range Test (DMRT) for mean differences. MS-Murashige and Skoog [8], BAP-Benzayl amino phosphate, IAA-Indole acetic acid]

\begin{tabular}{|c|c|c|c|c|c|}
\hline \multicolumn{6}{|c|}{ Media composition } \\
\hline Media & $\mathrm{BAP}, \mathrm{mg} / \mathrm{L}$ & $\begin{array}{l}\text { IAA, } \\
\text { mg/L }\end{array}$ & Callusing from explant & Shooting from callus & Shooting directly from explant \\
\hline MS & 0.00 & 0.00 & $33.02(30.244) \mathrm{c}$ & $6.1(10.310) a$ & $20.574(22.875) b c$ \\
\hline MS & 0.00 & 0.20 & $33.844(30.398) \mathrm{c}$ & 12.4(17.720)ab & $27.355(28.907) b$ \\
\hline MS & 0.50 & 0.00 & 39.441(35.993)bc & $24(25.360) \mathrm{b}$ & $21.726(24.37) b c$ \\
\hline MS & 0.50 & 0.20 & $41.316(37.254) a b c$ & $8.4(12.260) a$ & $31.18731 .838 b$ \\
\hline MS & 1.00 & 0.00 & $40.879(36.210) b c$ & 8.3(12.130)a & $49.814(44.503) \mathrm{a}$ \\
\hline MS & 1.00 & 0.20 & $49.201(46.483) \mathrm{a}$ & 11.9(17.310)a & $36.316(33.575) b$ \\
\hline MS & 2.00 & 0.00 & $50.396(45.978) a b c$ & $8.3(12.000) a$ & $23.46(24.727) b c$ \\
\hline MS & 2.00 & 0.20 & 42.652(38.895)abc & $8.3(12.200) a$ & $20.392(22.105) b c$ \\
\hline MS & 4.00 & 0.00 & 39.136(36.189)bc & No shooting & $11.666(14.584) \mathrm{c}$ \\
\hline MS & 4.00 & 0.20 & 43.545(40.336)abc & No shooting & $11.938(14.678) \mathrm{c}$ \\
\hline \multicolumn{3}{|c|}{ Probability } & 0.0031 & 0.018 & $<0.001$ \\
\hline \multicolumn{3}{|c|}{ LSD at $5 \%$} & 8.817 & 7.964 & 10.05 \\
\hline \multicolumn{3}{|l|}{$\mathrm{CV} \%$} & 3.522 & 3.540 & 5.807 \\
\hline
\end{tabular}

Table 4: F-Probability value for interaction between explants, media and incubation period.

\begin{tabular}{|c|c|c|c|}
\hline Interaction & $\begin{array}{l}\text { Callusing from } \\
\text { explant }\end{array}$ & Shooting from callus & $\begin{array}{lll}\begin{array}{l}\text { Shooting directly from } \\
\text { explant }\end{array} & \\
\end{array}$ \\
\hline Explant X Media & $<0.001$ & Only immature shoot used as explant & 0.0379 \\
\hline Explant $\mathrm{X}$ incubation period & $<0.001$ & Only immature shoot used as explant & $<0.001$ \\
\hline Media $X$ incubation period & 0.240 & 0.255 & $>0.650$ \\
\hline $\begin{array}{l}\text { Explant X Media X incubation } \\
\text { period }\end{array}$ & $>0.650$ & Only immature shoot used as explant & $>0.650$ \\
\hline
\end{tabular}

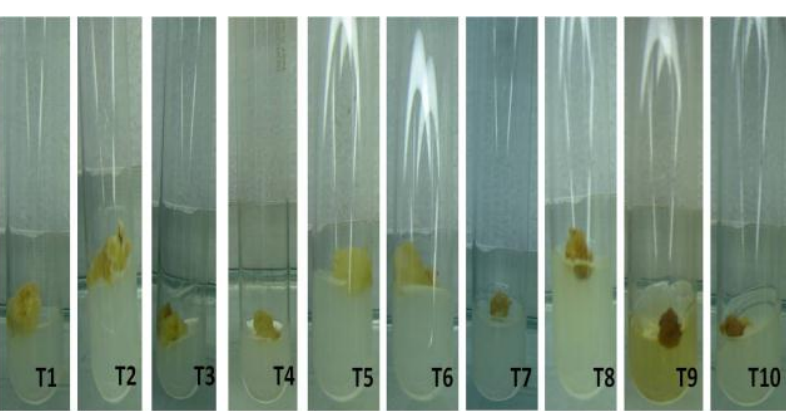

Figure 3. Effect of different level of hormones on mandarin orange mature flower bud explant

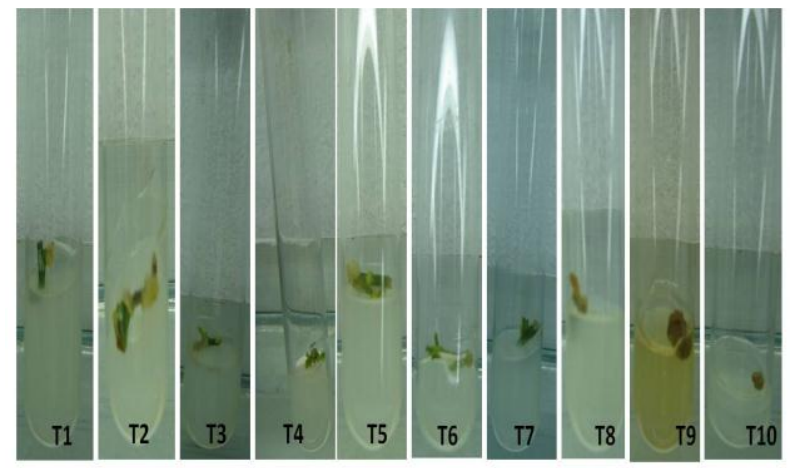

Figure 4. Effect of different level of hormones on mandarin orange immature-shoot with bud explant

\section{Shooting directly from ex-plant}

Flower bud didn't show any direct shooting nor does it produce any shoot after callusing. MS basal media $+4 \mathrm{mg} / 1 \mathrm{BAP}+0.2 \mathrm{mg} / 1$ IAA don't produce any shooting directly from immature shoot with single bud (Table 6). It didn't produce shoot from callus too (Table 3). Highest shooting was observed on MS basal media+1 mg/l BAP from in-vitro epicotyle $(71.722 \%)$ and from immature shoot with single bud $(27.906 \%)$ (Figure 1 and Figure 4). Similarly, immature shoot with single bud produced highest shooting in MS basal media+0.20mg/1 IAA (Table 6). However, Mendes et al. [9] observed that the percentage of shoots that produced roots in sweet orange variety 'Para' was significantly higher in media with NAA and IBA than with NAA alone.

\section{Conclusion}

Since the requirement of BAP for shoot development was genotype specific [9], for mandarin orange cv. 'Manakamana Local' to produce in-vitro scion for micro-grafting the MS basal media $+0.20 \mathrm{mg} / 1$ IAA in immature shoot is 
Table 5: Mean Percentage of the callusing from explants observed with respect to different media composition and explants used (LSD $=15.27$ at $5 \%$ ). [Value in parentheses is angular transformation; letters after mean is the comparisons using Duncan's Multiple Range Test (DMRT) for mean differences. MS-Murashige and Skoog [8], BAP-Benzayl amino phosphate, IAA-Indole acetic acid]

\begin{tabular}{|c|c|c|c|c|c|}
\hline \multicolumn{3}{|c|}{ Media composition } & \multirow{2}{*}{ Immature shoot with single bud } & \multirow{2}{*}{ Flower bud } & \multirow{2}{*}{$\begin{array}{l}\text { In-vitro shoot tip } \\
\text { cm long) }\end{array}$} \\
\hline Media & BAP mg/L & IAA mg/L & & & \\
\hline MS & 0.00 & 0.00 & 33.434(30.385)ghi & 65.622(60.061)bcd & $0.000(0.287) 1$ \\
\hline MS & 0.00 & 0.20 & 20.677(21.556)hijk & 80.853(69.352)abc & $0.000(0.287) 1$ \\
\hline MS & 0.50 & 0.00 & 25.618(26.992)ghij & $92.704(80.700) a$ & $0.000(0.287) 1$ \\
\hline MS & 0.50 & 0.20 & 30.737(30.366)ghi & $93.208(81.108) a$ & $0.000(0.287) 1$ \\
\hline MS & 1.00 & 0.00 & 31.998(31.180)ghi & 90.635(77.164)ab & $0.000(0.287) 1$ \\
\hline MS & 1.00 & 0.20 & 34.999(33.592)fgh & $88.644(77.054) a b$ & 23.958(28.802)ghij \\
\hline MS & 2.00 & 0.00 & 13.196(15.258)ijkl & $90.703(79.234) a$ & 47.289(43.443)efg \\
\hline MS & 2.00 & 0.20 & 8.097(10.009)kl & 60.832(56.382)cde & 59.028(50.294)def \\
\hline MS & 4.00 & 0.00 & $0.000(0.287) 1$ & 77.197(68.928)abc & $40.208(39.354) \mathrm{fg}$ \\
\hline MS & 4.00 & 0.20 & 11.668(12.125)jkl & $77.300(68.737) \mathrm{abc}$ & 41.667(40.146)efg \\
\hline
\end{tabular}

Table 6: Mean Percentage of the shooting directly from explants observed with respect to different media composition and explants used $(\mathrm{LSD}=14.21$ at $5 \%)$. [Value in parentheses is angular transformation; letters after mean is the comparisons using Duncan's Multiple Range Test (DMRT) for mean differences. MS-Murashige and Skoog [8], BAP-Benzayl amino phosphate, IAA-Indole acetic acid]

\begin{tabular}{|c|c|c|c|c|}
\hline \multicolumn{5}{|c|}{ Media composition } \\
\hline Media & $\begin{array}{l}\mathrm{BAP}, \\
\mathrm{mg} / \mathrm{L}\end{array}$ & $\begin{array}{l}\text { IAA, } \\
\mathrm{mg} / \mathrm{L}\end{array}$ & Immature shoot with single bud & In-vitro shoot tip ( $2 \mathrm{~cm}$ long) \\
\hline MS & 0.00 & 0.00 & 12.938(13.974)efg & 28.209(31.775)bcd \\
\hline MS & 0.00 & 0.20 & 27.117(26.317)bcdef & 27.593(31.497)bcd \\
\hline MS & 0.50 & 0.00 & $26.236(24.501) \mathrm{cdef}$ & $17.216(24.240)$ cdef \\
\hline MS & 0.50 & 0.20 & 26.930(27.202)bcde & $35.444(36.475) \mathrm{bc}$ \\
\hline MS & 1.00 & 0.00 & 27.906(28.415)bcde & $71.722(60.590) a$ \\
\hline MS & 1.00 & 0.20 & $26.314(24.306) \mathrm{cdef}$ & $46.319(42.844) b$ \\
\hline MS & 2.00 & 0.00 & 17.356(16.732)def & 29.565(32.721)bcd \\
\hline MS & 2.00 & 0.20 & 22.224(18.764)def & 18.561(25.446)cdef \\
\hline MS & 4.00 & 0.00 & $9.878(9.519) \mathrm{fg}$ & 13.453(19.648)cdef \\
\hline MS & 4.00 & 0.20 & $0.000(0.287) \mathrm{g}$ & 23.874(29.069)bcde \\
\hline
\end{tabular}

best for high shooting. Similarly, the MS basal media $+0.5 \mathrm{mg} / 1 \mathrm{BAP}$ is suitable for shooting from callus $(24 \%)$ on this cultivar.

\section{References}

1. MOAD: Statistical Information on Nepalese Agriculture 2012/13. Government of Nepal. Ministry of Agriculture Development. Agriculture Business Promotion and Statistical Division, Statistics Section, Singhadurbar, Kathmandu, Nepal, 2013.

2. FAO: Training manual for combating citrus decline problem in Nepal. Directorate of Agriculture, Ministry of Agriculture and Cooperatives, Government of Nepal and Food and Agriculture Organization of United Nations, 2011, TCP/NEP/3302:(D).

3. Sharma S, Singh B, Rani G, Zaidi AA, Hallan V, Nagpal A, Virk GS: Production of Indian citrus ringspot virus free plants of Kinnow employing chemotherapy coupled with shoot tip grafting. J Cen Eur Agri. 2007, 8(1): 1-8.

4. Nauer EM, Roistacher CN, Carson TL, Murashigue $\mathrm{T}$ : In-vitro shoot tip grafting to eliminate citrus viruses and virus-like pathogens produces uniform budliness. Hortscience 1983, 18: 308-309.

5. Navarro L: Shoot-tip grafting in-vitro (STG) and its application: A review. Proceeding of the International Society of Citriculture 1981, 1: 452-456.

6. Youtsey CO: A method for virus-free propagation of citrus: shoot tip grafting. Citrus Industry 1978, 59:39-47.

7. Martin ML, Duran-Vila N: Conservation of citrus germplasm in-vitro. J Amer Soc Hort Sci. 1991, 116 (4): 740-746.

8. Murasige T, Skoog F: A revised medium for rapid growth and bioassays with tobacco tissue cultures. Physiol. Plant. 1962, 15: 473-497.

9. Mendes AFS, Cidade LC, Manzoli GN, Otoni WC, Filho WSS, Costa MGC: Tissue culture parameters in sweet orange cultivars. Pesq. Agropec. Bras, Brasilia 2008, 43(8): 1093-1096. 